\title{
Optical coherence tomography angiography in Leber hereditary optic neuropathy
}

Figure Characterizing the progression of Leber hereditary optic neuropathy using optical coherence tomography angiography and fundus photography of a patient's left eye

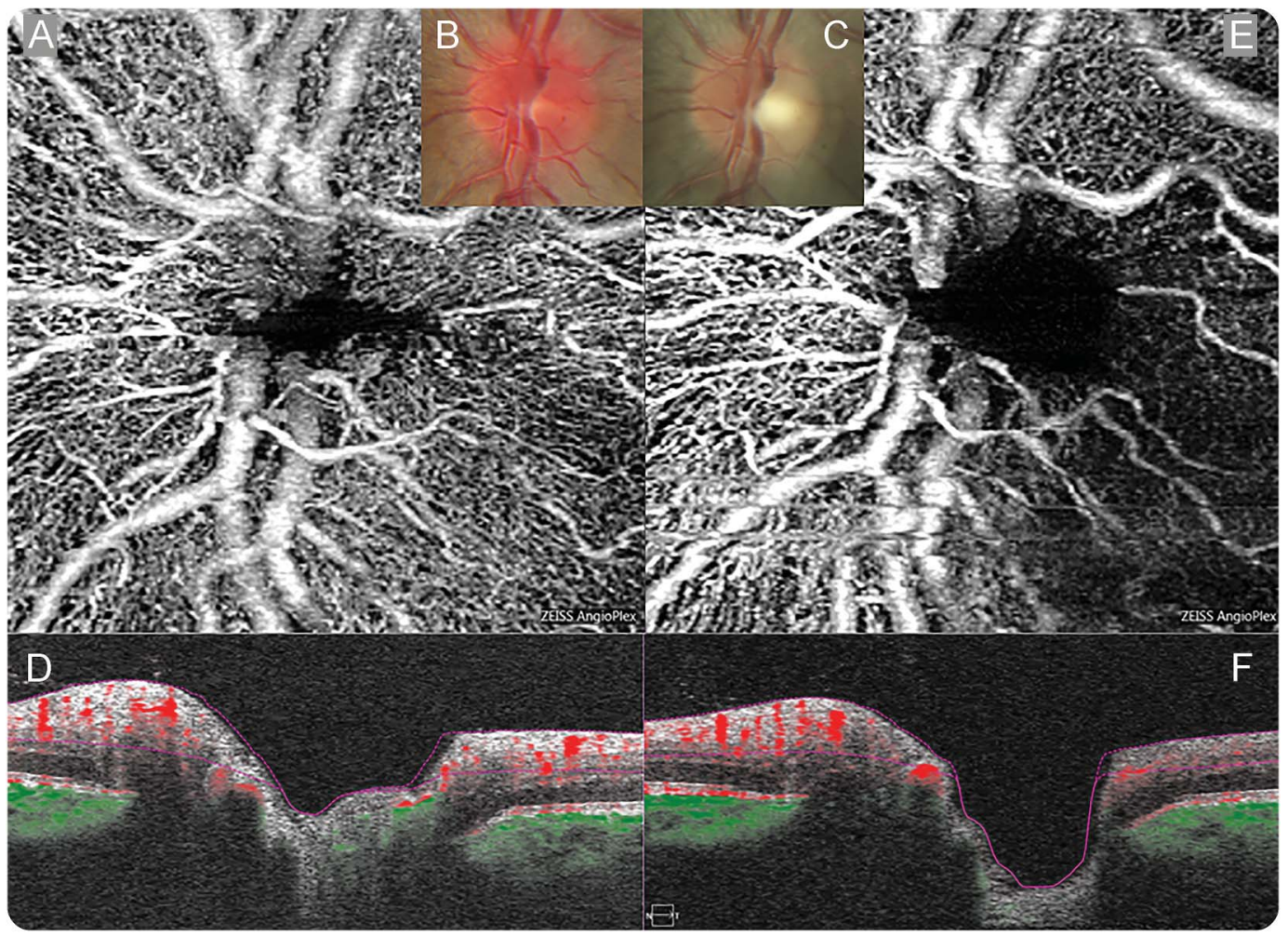

(A, B, D) Note acute phase optic disc hyperemia and circumpapillary telangiectasias. (C, E, F) Three months after presentation, note significant capillary dropout in the papillomacular bundle and obvious disc cupping.

A 17-year-old man had acute vision loss OS (visual acuity 20/40), having lost vision OD months before (20/400). There were cecocentral scotomas OU. Mitochondrial DNA testing revealed a T14484C mutation, suggestive of Leber hereditary optic neuropathy (LHON), which results in painless sequential vision loss. Acutely, there is hyperemia of the optic nerve, circumpapillary microangiopathy, and dilated, tortuous vasculature'; the pathognomonic finding is nerve swelling without leakage on fluorescein angiography. Chronically, the optic nerve develops atrophy, sometimes with cupping. ${ }^{2}$ Optical coherence tomography angiography provides rapid, high-resolution visualization of retinal vasculature without dye injection, and is a novel imaging modality in LHON (figure).

Joaquin O. De Rojas, MD, Nailyn Rasool, MD, Royce W.S. Chen, MD, Jason Horowitz, MD, Jeffrey G. Odel, MD From Columbia University Medical Center, New York, NY.

Author contributions: Joaquin De Rojas: study concept and design, acquisition of data, analysis and interpretation of data, figure design, critical revision of manuscript for intellectual content. Nailyn Rasool: study concept and design, analysis and interpretation of data, critical revision of manuscript for intellectual content. Royce Chen: analysis and interpretation of data, figure design, critical revision of manuscript for intellectual content. Jason Horowitz: study concept and design, analysis and interpretation of data, figure design. Jeffrey Odel: study concept and design, critical revision of manuscript for intellectual content.

Study funding: Funded by Research to Prevent Blindness unrestricted grant. 
1. Nikoskelainen E, Hoyt WF, Nummelin K, Schatz H. Fundus findings in Leber's hereditary optic neuroretinopathy: III: fluorescein angiographic studies. Arch Ophthalmol 1984;102:981-989.

2. Ortiz RG, Newman NJ, Manoukian SV, Diesenhouse MC, Lott MT, Wallace DC. Optic disk cupping and electrocardiographic abnormalities in an American pedigree with Leber's hereditary optic neuropathy. Am J Ophthalmol 1992;113:561-566.

\section{Quarter 4 2016 AAN Practice Management Webinars: The FASTEST Way to Improve Your Practice}

Timely. Affordable. Convenient. In just one hour, you can learn the information on topics that affect the success of your practice, from coding and reimbursement to working with new technologies and health system changes. AAN members pay only $\$ 99$ per live or recorded session-or get all 10 webinars for only $\$ 189$ - and you can earn CME credit! Visit AAN.com/view/pmw16 to register for these webinars:

- October 11: Don't Just Phone It in: A Guide to Teleneurology

- November 8: Getting the Most Out of Your Technology: HIT and Your Patients

- December 13: Attend FREE! Decoding the 2017 Medicare Fee Schedule and MACRA Rule

\section{Visit the Neurology ${ }^{\circledR}$ Website at Neurology.org}

- Enhanced navigation format

- Increased search capability

- Highlighted articles

- Detailed podcast descriptions

- RSS Feeds of current issue and podcasts

- Personal folders for articles and searches

- Mobile device download link

- AAN Web page links

- Links to Neurology Now ${ }^{\circledR}$, Neurology $\operatorname{Today}^{\circledR}$, and Continuum ${ }^{\circledR}$

- Resident \& Fellow subsite

[N Fircosook Find Neurology ${ }^{\circledR}$ on Facebook: http://tinyurl.com/neurologyfan

twitter Follow Neurology ${ }^{\circledR}$ on Twitter: https://twitter.com/GreenJournal 


\section{Neurology}

Optical coherence tomography angiography in Leber hereditary optic neuropathy Joaquin O. De Rojas, Nailyn Rasool, Royce W.S. Chen, et al. Neurology 2016;87;2065-2066

DOI 10.1212/WNL.0000000000003313

\section{This information is current as of November 7, 2016}

\section{Updated Information \& Services}

Supplementary Material

\section{References}

Subspecialty Collections

Permissions \& Licensing

\section{Reprints}

including high resolution figures, can be found at: http://n.neurology.org/content/87/19/2065.full

Supplementary material can be found at: http://n.neurology.org/content/suppl/2016/11/07/WNL.0000000000003 313.DC1

This article cites 2 articles, 0 of which you can access for free at: http://n.neurology.org/content/87/19/2065.full\#ref-list-1

This article, along with others on similar topics, appears in the following collection(s):

Optic nerve

http://n.neurology.org/cgi/collection/optic_nerve

Information about reproducing this article in parts (figures,tables) or in its entirety can be found online at:

http://www.neurology.org/about/about_the_journal\#permissions

Information about ordering reprints can be found online:

http://n.neurology.org/subscribers/advertise

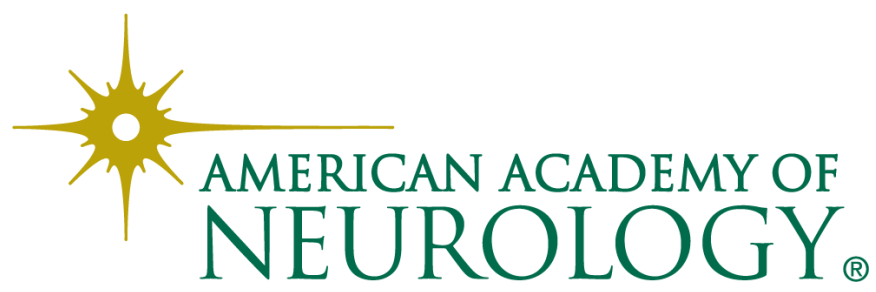

